\title{
Pembelajaran IPA dengan Model Problem Based Learning Berbantuan Media Audio Visual Meningkatkan Pemahaman Konsep Siswa
}

\author{
I Kadek Kurniawan \\ Program Studi Pendidikan Guru Sekolah Dasar, Universitas Pendidikan Ganesha \\ kurni138@gmail.com
}

Desak Putu Parmiti

Program Studi Teknologi Pendidikan, Universitas Pendidikan Ganesha (9 Pt) dp-parmiti@undiksha.ac,id

Nyoman Kusmariyatni

Program Studi Pendidikan Guru Sekolah Dasar, Universitas Pendidikan Ganesha nyoman.kusmariyatni@undiksha.ac.id

\author{
A R T I C L E I N F O \\ Article history: \\ 1 Juli 2020 Received in \\ revised form \\ 30 Agustus 2020 \\ Accepted 28 September 2020 \\ Available online \\ 30 September 2020

\section{Kata Kunci:} \\ Problem Based Learning, \\ Audio Visual, Pemahaman \\ Konsep IPA \\ Keywords: \\ Problem Based Learning, \\ Audio Visual, and Science \\ Course Comprehensio.
}

\begin{abstract}
AB S T R A K
Penelitian ini bertujuan untuk menganalisis pengaruh model pembelajaran PBL berbantuan media audio visual terhadap pemahaman konsep IPA siswa kelas V SD. Jenis penelitian yang dilaksanakan merupakan Eksperimen Semu dengan desain penelitian Non-equivalent Posttest Only Control Group Design. Populasi penelitian ini adalah siswa kelas V yang berjumlah 129 siswa. Sampel penelitian berjumlah 81 siswa, yang diambil dengan menggunakan teknik simple random. Data kemampuan pemahaman konsep IPA dikumpulkan menggunakan instrumen tes berbentuk soal objektif (pilihan ganda). Data yang diperoleh, selanjutnya dianalisis menggunakan teknik analisis statistik deskriptif dan inferensial (Uji-t). Berdasarkan perhitungan Uji-t diperoleh data thitung $=$
\end{abstract} $2,087>$ ttabel $=2,00$ pada taraf signifikansi $5 \%$ dengan $\mathrm{dk}=79$. Hal ini berarti, terdapat perbedaan yang signifikan kemampuan pemahaman konsep IPA antara kelompok eksperimen dan control. Jadi, dapat disimpulkan bahwa, terdapat pengaruh yang signifikan model PBL berbantuan media audio visual terhadap pemahaman konsep IPA siswa kelas V SD. Implikasi penggunaan model PBL berbantuan media audio visual, yaitu siswa menjadi aktif dalam mengikuti pembelajaran. Pembelajaran PBL yang mengacu pada permasalahan membuat siswa menjadi terlatih dalam memahami sebuah konsep. 
significant effect on PBL Model assisted by Audio Visual Media toward fifth-grade students' science concept comprehension. The implications of using the PBL Model assisted by Audio Visual Media is that students become active in following learning processes. The PBL learning that refers to the problem of making students trained in Understanding a concept.

\section{PENDAHULUAN}

Proses pendidikan adalah suatu proses pengembangan atau peningkatan potensi seseorang. Undang-Undang Republik Indonesia Nomor 20 Tahun 2003 tentang sistem Pendidikan Nasional menyatakan "Pendidikan adalah usaha sadar dan terencana untuk mewujudkan suasana belajar dan proses pembelajaran agar peserta didik secara aktif mengembangkan potensi dirinya untuk memiliki kekuatan spiritual keagamaan, pengendalian diri, kepribadian, kecerdasan akhlak mulia, serta keterampilan yang diperlukan dirinya, masyarakat, bangsa dan negara". Dalam mewujudkan hal tersebut, berbagai upaya dilakukan pemerintah untuk meningkatkan kualitas pendidikan, salah satunya dengan perubahan kurikulum yang terus disempurnakan untuk mencapai tujuan pendidikan.

Selain pengembangan kurikulum, pada pelaksanaan pembelajaran di kelas guru harus mampu menentukan atau memilih model dan strategi pembelajaran yang tepat (Sinabariba, 2017). Cara guru menyampaikan materi pembelajaran sangat mempengaruhi minat siswa dan kelancaran proses pembelajaran yang akhirnya akan berpengaruh terhadap pemahaman konsep siswa. Agar suatu pembelajaran dapat bermakna bagi siswa, guru harus mengetahui tentang objek yang akan diajarnya sehinga dapat mengajarkan materi tersebut dengan penuh dinamika dan inovasi. Demikian halnya dengan pembelajaran Ilmu Pengetahuan Alam.

Ilmu Pengetahuan Alam merupakan salah satu muatan pokok dalam kurikulum pendidikan di Indonesia yang dipadukan dengan muatan materi lainnya khusus pada jenjang sekolah dasar. Wisudawathi \& Sulistyowati (2014: 40) menyatakan "mata pelajaran IPA bertujuan agar siswa memahami alam dan mampu memecahkan masalah yang mereka jumpai di sekitar". Ilmu Pengetahuan Alam (IPA) berhubungan dengan cara mencari tahu tentang alam secara sistematis, sehingga bukan hanya kumpulan pengetahuan yang berupa fakta-fakta tetapi suatu proses penemuan berupa pemahaman konsep juga diterapkan. Hal ini menunjukkan bahwa pembelajara IPA dapat digunakan sebagai wahana dalam melatih proses dan sikap ilmiah siswa. Oleh karena itu, hasil yang diperoleh dalam pemebalajaran IPA seharusnya menjadi cermin seberapa dalam pengetahuan dan pemahaman konsep yang dimiliki oleh siswa. Oleh sebab itu pembelajaran IPA harus menekankan pada pemberian pengalaman secara langsung.

Masalah yang sering dihadapi dalam dunia pendidikan khususnya di Indonesia adalah lemahnya proses pembelajaran. Hal ini terbukti dari hasil survie PISA tahun 2018 untuk kategori sains, Indonesia berada pada peringkat 71 dari 80 negara yang mengikuti program ini. Skor rata-rata Indonesia adalah 398 yang terpaut sangat jauh dengan China yang berada di peringkat pertama dengan skor rata-rata 590 (Permana dkk., 2019). Hasil survei TIMSS tahun 2015 juga menunjukan, keterampilan sains Indonesia tergolong rendah. Indonesia berada pada peringkat 45 dari 48 negara. Rata-rata skor Indonesia adalah 397 (Hadi \& Novaliyosi, 2019). Berdasarkan hasil studi dokumentasi yang telah dilakukan di SD N Gugus VIII Kecamatan Buleleng khususnya di kelas V yang dilakukan pada tanggal 21-24 Oktober 2019 diketahui bahwa hasil belajar pada mata pelajaran IPA masih rendah. Hal ini dapat dilihat dari perolehan presentase pada Tabel 1. 
Tabel 1. Rata-rata dan Persentase PTS pada Ranah Kognitif IPA Kelas IV SD di Gugus VI Kecamatan Buleleng

\begin{tabular}{|c|c|c|c|c|c|c|c|c|}
\hline \multirow[t]{2}{*}{ No. } & \multirow[t]{2}{*}{ Sekolah } & \multirow[t]{2}{*}{$\begin{array}{c}\text { Jumlah } \\
\text { Siswa }\end{array}$} & \multirow[t]{2}{*}{ KKM } & \multicolumn{2}{|c|}{$\begin{array}{c}\text { Jumlah Siswa } \\
\text { yang sudah } \\
\text { mencapai KKM }\end{array}$} & \multicolumn{2}{|c|}{$\begin{array}{c}\text { Jumlah Siswa } \\
\text { yang belum } \\
\text { mencapai KKM }\end{array}$} & \multirow[t]{2}{*}{ Rata-rata } \\
\hline & & & & Siswa & $\%$ & Siswa & $\%$ & \\
\hline 1. & SD Negeri 1 Beratan & 10 & 70 & 2 & $20 \%$ & 8 & $80 \%$ & 65,6 \\
\hline 2. & SD Negeri 2 Liligundi & 18 & 70 & 4 & $22,2 \%$ & 14 & $77,8 \%$ & 65,5 \\
\hline 3. & SD Negeri 1 Kendran & 20 & 58 & 7 & $35 \%$ & 13 & $65 \%$ & 64,4 \\
\hline 4. & $\begin{array}{l}\text { SD Negeri } 1 \text { Paket } \\
\text { Agung }\end{array}$ & 41 & 70 & 22 & $54 \%$ & 19 & $46 \%$ & 67,4 \\
\hline 5. & $\begin{array}{l}\text { SD Negeri } 2 \text { Paket } \\
\text { Agung }\end{array}$ & 40 & 70 & 19 & $48 \%$ & 21 & $52 \%$ & 68 \\
\hline
\end{tabular}

(Sumber:Arsip Nilai Siswa SD Gugus VIII Kecamatan Buleleng, 2019)

Berdasarkan data pada tabel 1, diketahui bahwa ketuntasan belajar IPA siswa kelas V di Gugus VIII Kecamatan Buleleng, masih terbilang rendah ini dibuktikan dari persentase pencapaian KKM, bahwa lebih banyak siswa yang tidak mencapai KKM dibandingkan siswa yang mencapai KKM dalam pembelajaran IPA, ini artinya hasil pembelajaran yang dilaksanakan masih belum sesuai dengan apa yang diharapkan, sehingga perlu adanya perubahan untuk peningkatan kembali, karena hal tersebut merupakan suatu masalah yang harus diatasi. Selain dari data tersebut juga dilakukan observasi pelaksanaan belajar mengajar pada guru kelas V di gugus VIII kecamatan Buleleng.

Dilihat pada pembelajaran IPA, pertama dalam menyampaikan materi pembelajaran guru masih menggunakan metode ceramah dan tidak diimbangi dengan model yang inovatif serta media yang mendukung. Kedua, kemampuan pemahaman konsep siswa masih kurang, karena pada saat awal pembelajaran masalah yang diberikan kurang dipahami oleh siswa, serta siswa terbiasa hanya mendengarkan penjelasan dari guru sehingga siswa kurang aktif dan terlibat langsung dalam mengikuti proses pembelajaran. Sejalan dengan hal tersebut menurut Darma (dalam Setyawati, dkk, 2014) pembelajaran yang masih didominasi oleh guru menyebabkan siswa pasif, hanya menerima dan melakukan apa yang diminta oleh guru sehingga siswa kurang aktif dalam menemukan konsep materi secara mandiri. Hasil observasi tersebut juga didukung dengan hasil wawancara dengan guru kelas V SD di Gugus VIII Kecamatan Buleleng yang menyatakan bahwa siswa masih kesulitan dalam menuangkan ide atau gagasan suatu masalah yang diberikan oleh guru, karena dalam pembelajaran IPA tidak hanya materi yang dijelaskan namun siswa dituntut untuk mampu melakukan. Hal tersebut juga dibuktikan dengan ratarata hasil belajar siswa pada mata pelajaran IPA masih belum memenuhi Kriteria Ketuntasan Minimal (KKM), sehingga dapat dikatakan bahwa pemahaman konsep siswa pada mata pelajaran IPA masih kurang. Dampak yang akan terjadi, jika permasalahan ini tidak segera diatasi adalah rendahnya pemahaman konsep IPA siswa, seperti terbukti dari hasil survie TIMSS tahun 2015 dan hasil survei PISA tahun 2018 yang sudah dipaparkan di atas.

Merujuk pada permasalahan tersebut, maka perlu menciptakan proses pembelajaran yang dapat meningkatkan keaktifan siswa, sehingga dapat meningkatkan pemahaman konsep IPA siswa. Widyanto (2016) menyatakan bahwa IPA adalah suatu pengetahuan sistematika tentang alam yang memuat tentang gejala-gejala alam dan peristiwa-peristiwa alam yang bukan hanya memuat fakta namun memuat sikap ilmiah dan metode ilmiah. Sedangkan menurut Powler (dalam Samatowa, 2010) bahwa IPA merupakan ilmu yang berkaitan dengan gejala alam yang tersusun secara teratur, berlaku umum yang berupa kumpulan dari hasil observasi dan eksperimen artinya pengetahuan itu tersusun dalam suatu sistem, tidak berdiri sendiri, satu dengan lainnya saling berkaitan, saling menjelaskan 
sehingga seluruhnya merupakan satu kesatuan yang utuh, sedangkan berlaku umum artinya pengetahuan itu tidak hanya berlaku atau beberapa orang dengan cara eksperimentasi yang sama akan memperoleh hasil yang sama atau konsisten. Sedangkan Purnamawati dkk (2014) menyatakan IPA merupakan salah satu mata pelajaran pokok dalam kurikulum pendidikan, dan IPA juga mempelajari tentang peristiwa-peristiwa yang terjadi di alam. Jadi dapat dipahami bahwa pembelajaran IPA merupakan pembelajaran berdasarkan pada prinsip dan proses dimana dapat menumbuhkan sikap ilmiah siswa terhadap konsep-konsep IPA. Oleh karena itu, pembelajaran IPA di sekolah dasar dilakukan terhadap kumpulan konsep IPA. Kadir (2015) mengemukakan bahwa pembelajaran IPA bertujuan untuk memberikan bekal kepada peserta didik agar mampu memiliki kemampuan positif terhdap alam semesta dengan menyadari keindahan dan fenomena yang menakjubkan dengan memupuk sikap ilmiah.

Adapun ruang lingkup pembelajaran IPA di SD dalam Standar Kompetensi dan Kompetensi Dasar dari kelas I sampai kelas VI yang secara bertahap sesuai dengan tingkat perkembangan siswa, dari materi yang konkrit sampai materi yang abstrak, dan dari materi yang sederhana sampai materi yang rumit (Riananda \& Nurdyansyah, 2017). Berikut merupakan ruang lingkup pembelajaran IPA yang ada di Sekolah Dasar menurut Saputro (2017) yaitu. 1) makhluk hidup dalam proses kehidupannya terdiri dari manusia, hewan dan tumbuhan, 2) benda atau materi, sifat-sifat dan kegunaanya terdiri dari zat padat, cair dan gas, 3) energi dan perubahannya terdiri dari gaya, bumi, panas, magnet, cahaya, dan pesawat sederhana, 4) bumi dan alam semeseta terdiri dari tanah, bumi, tata surya, dan benda-benda langit. Pada pembelajaran IPA di SD diharapkan dapat menjadi wahan bagi siswa untuk mempelajari diri sendiri dan alam sekitar. Dalam mengikuti pembelajaran terutama yang berkaitan dalam kehidupan sehari-hari lingkungan akan memudahkan siswa dalam menangkap materi pembelajaran. Jika seringkali itu dilakukkan maka pembelajaran akan sangat efektif, serta siswa akan terlatih untuk melakukkan sesuatu apabila didasari oleh pengalaman. Selain siswa guru dalam mengajarkan harus kreatif dan inovatif dalam mengemas pembelajaran supaya menarik dan menyenangkan sehingga dapat membuat siswa termotivasi untuk belajar dan mampu meningkatkan pemahaman konsep siswa.

Pemahaman adalah suatu kemampuan yang berkaitan tentang intelektual yang dimiliki siswa, menurut Susanto (2013) pemahaman dapat dikelompokkan dalam aspek tertentu, dengan kriteria sebagai berikut; 1) Pemahaman adalah penguasaan untuk menjelaskan dan menginterpretasikan sesuatu, 2) Pemahaman tidak hanya sekedar mendapat informasi untuk mengetahui sesuatu, tetapi mengingat kembali pengalaman yang pernah dilakukan dan memproduksi apa yang pernah dipelajar jadi dapat diartikan pemahaman lebih dari sekedar mengetahui, dan 3) Pemahaman merupakan suatu rangkaian bertahap dimana setiap tahap memiliki kemampuan terpisah/tersendiri seperti menterjemahkan, menafsirkan, menganalisis dan mengevalusai. Konsep dapat didefinisikan sebagai sesuatu yang berhubungan erat dengan intelektual siswa, kemampuan menerapkan yang diturunkan dari fakta, pengalaman dan pristiwa yang terjadi (Aderson \& Krathwohl, 2010). Sehingga pemahaman konsep IPA dapat diartikan sebagai kemampuan siswa dalam memahami sebuah makna secara ilmiah, baik secara konsep maupun secara teori untuk mampu memecahka masalah. Pemahaman konsep yang kurang mapan dapat ditandai dengan tidak memahami makna konten pengetahuan, definisi, dan alasan dari bagian pengetahuan yang saling terkait. Sejalan dengan penjelasan tersebut Holme, Luxford, \& Brandriet (dalam Sadiqin, dkk, 2017), "menyimpulkan definisi pemahaman konsep dalam konteks IPA berdasarkan pendapat para pakar adalah kemampuan siswa dalam memahami hubungan konsep satu sama lain sehingga bisa diterapkan untuk memecahkan masalah".

Salah satu alternatif yang dapat digunakan untuk mengatasi masalah tersebut adalah menggunakan model pembelajaran Problem Based Learing. Model ini dipilih karena Problem Based Learning memiliki karakteristik yaitu penyelidikan autentik, Trianto (dalam Hakim, dkk, 2016) menyatakan salah satu model yang dapat digunakan untuk 
meningkatkan pemahaman peserta didik terhadap materi dan juga menuntut peserta didik untuk lebih aktif dalam proses pembelajaran yaitu model pembelajaran berbasis masalah yaitu Problem Based Learning. Selanjutnya Trianto (2007) menyatakan dalam model Problem Based Learningsiswa diharuskan dapat melakukan penyelidikan autentik yang meliputi menganalisis dan mengidentifikasi masalah, membuat hipotesis, mengumpulkan dan menganalisa informasi, melakukan percobaan (eksperimen), dan merumuskan simpulan, sehingga dapat memperkuat pemahaman konsep siswa. Selain itu model Problem Based Learning juga sangat berpengaruh dalam pembelajaran IPA, karena berkaitan dengan masalah dalam kehidupan di sekitar lingkungan. Model PBL ialah sebuah skema pembelajaran yang berorientasi pada masalah. Menurut Kono (2016) model PBL adalah proses pembelajaran yang didasari sebuah persoalan dengan tujuan siswa memahami sebuah konsep melalui permasalahan. Model PBL adalah model yang mengedepankan keaktifan siswa guna memperoleh sebuah solusi atas sebuah persoalan (Saleh, 2013). Hal senada juga disampaikan Gading, dkk (2018) bahwa model PBL adalah desain pembelajaran student centred, guru bertanggungjawab dalam mempersiapkan berbagai persoalan sebagai bahan diskusi. Berpatokan pada penjelasan tersebut bisa dirumuskan, model PBL adalah proses pembelajaran yang diawali dengan pengajuan masalah oleh guru, sebagai upaya pembiasaan diri berpikir kritis dan bekerja sama untuk mengatasi sebuah persoalan.

Adapun sintak Problem Based Learning Arends (Nafiah \& Suyanto, 2014) yaitu; (1) mengorientasikan siswa terhadap suatu masalah, (2) mengorientasikan siswa untuk belajar, (3) membimbing penyelidikan individual ataupun kelompok, (4) mengembangkan dan menyajikan hasil karya, dan (5) menganalisis dan mengevaluasi pemecahan masalah. Selain itu kelebihan dari model Problem Based Learning menurut Anwar (2017) diantaranya: (a) model pemecahan masalah dapat merangsang munculnya kemampuan untuk menentukan pengetahuan baru bagi peseta didik, (b) Pemecahan masalah mampu meningkatkan keaktifan peseta didik dalam proses belajar dikelas, (c) model pemecahan masalah dapat membantu peserta didik menghubungkan pengetahuan dan pengalamannya dalam memahami masalah dalam kehidupan nyata, (d) model pembelajaran pemecahan masalah dianggap lebih menyenangkan dan disuaki oleh peserta didik, dan (e) model pemecahan masalah dapat memberikan kesempatan pada peserta didik untuk mengaplikasikan pengetahuannya dalam dunia nyata. Dalam model PBL siswa membentuk sebuah kelompok untuk melakuka diskusi. Siswa terlihat lebih leluasa ketika berdiskusi dengan anggota kelompoknya dibandingkan langsung bertanya kepada guru. Santosa (2018) menyatakan bahwa pembelajaran yang mengutamakan adanya aktivitas kerja sama antarsiswa dapat meningkatkan keaktifan siswa, menumbuhkan kemauan diri untuk belajar, dan mealatih kecakapan bekerja dalam kelompok. Selanjutnya Simbolon (2017) menjelaskan bahwa, pembelajaran yang dilaksanakan dalam bentuk kelompok telah mampu meningkatkan motivasi belajar perserta didik, sehingga mau berkolaborasi dengan temannya untuk mengatasi persoalan yang dihadapi. Lumentut dkk (2015) juga menjelaskan keaktifan siswa dalam diskusi dan tanya jawab meningkat dengan diterapkannya pembelajaran yang menekankan kolaborasai antarsiswa. Jadi dapat disimpulkan model PBL mampu meningkatkan keaktifan siswa dalam berinteraksi.

Penggunaan model PBL akan lebih efiktif apabila dimulai dengan aktifitas yang dapat membuat suasana menjadi lebih menyenangkan. Menurut Pramita \& Agustini (2016), tujuan pembelajaran akan lebih mudah tercapai apabila proses pembelajaran berlangsung menyenangkan dan tidak monoton. Aktivitas yang bisa dilakukan, salah satunya adalah memberikan siswa pembelajaran melalui media berupa auido visual, yang bertujuan untuk menarik perhatian siswa untuk masuk kedalam pembelajaran. Sejalan dengan hal tersebut, dalam penyampaian masalah, diperlukan adanya media yang memegang peranan sangat penting dalam pembelajaran sebagai perantara atau pengantar materi yang disajikan agar mampu dipahami dengan baik oleh siswa. Gearlach \& Elly (dalam Fahturohman \& Sutikno, 2011) menyatakan bahwa media apabila dipahami secara 
garis besar adalah manusia, materi atau kejadian yang membangun suatu kondisi yang membuat siswa mampu memperoleh pengetahuan, ketrampilan atau sikap. Sejalan dengan pendapat tersebut Atwi Suprman (dalam Fahturohman \& Sutikno, 2011: 65) mendefinisikan media merupakan alat yang digunakan untuk menyalurkan pesan atau informasi dari pengirim kepada penerima. Selanjutnya Sukiman (2012: 12) menyatakan media pembelajaran adalah segala sesuatu yang dapat digunakan untuk menyalurkan pesan dari pengirim ke penerima sehingga merangsang pikiran, perasaan, perhatian, dan minat serta kemauan peserta didik sedemikian rupa sehingga proses belajar terjadi dalam rangka mencapai tujuan pembelajaran secara efektif. Jenis media dibagi kedalam media auditif (suara), visual (gambar) serta media audio visual. Dalam penelitian ini model Problem Based Learning dibantu menggunakan media audio visual, menurut Arsyad (dalam Hastuti \& Budianti (2014) media audio visual adalah media penyampaian informasi yang memiliki karakteristik audio (suara) dan visual (gambar) dengan media audio visual diharapkan dapat menyajikan masalah atau materi yang dapat menarik perhatian dan minat siswa dalam mengikuti proses pembelajaran dalam kelas.

Maka dapat diambil kesimpulan, bahwa model pembelajaran Problem Based Learning berbantuan media audio visual adalah model pembelajaran yang menekankan pada permasalahan yang terjadi di dunia nyata yang dibahas dan dipecahkan dengan bantuan media audio visua yang dilengkapi dengan sajian suara dan gambar yang sesuai sehingga dapat menarik perhatian siswa, meningkatkan keaktifan siswa, serta dapat mengembangkan kemandirian peserta didik melalui pemecahan masalah. Oleh sebab itu model pembelajaran Problem Based Learning dibantu dengan media audio visual diharapkan dapat menimbulkan keinginan siswa dalam belajar sehingga dapat meningkatkan pemahaman konsep siswa kelas $\mathrm{V}$ khususnya dalam pembelajaran IPA. Untuk menganalisis pengaruh dari penggunaan model Problem Based Learning berbantuan media audio visual terhadap pemahaman konsep siswa, maka dari itu dilakukan penelitian eksperimen dengan mengaplikasikan salah satu model pembelajaran dengan judul Pengaruh model pembelajaran Problem Based Learning berbantuan media audio visual terhadap pemahaman konsep IPA siswa kelas V Gugus VIII Kecamatan Buleleng

\section{METODE PENELITIAN}

Penelitian ini termasuk jenis eksperimen semu. Jenis ini merupakan memiliki kelompok kontrol yang berperan sebagai kontrol pelekasanaan eksperimen, tetapi sifatnya terbatas kerena tidak semua variabel luar bisa dikontrol (Sugiyono, 2017). Desain ini dipilih karena keterbatasan kemampuan pengamatan perilaku peserta didik ketika di luar sekolah. Bentuk desain yang dipilih adalah non equivalent post-test only control group design. Desain ini memberikan gambaran bahwa tes diberikan hanya pada akhir perlakuan atau setelah materi yang dibelajarkan selesai (post-test). Populasi dalam penelitian ini adalah seluruh kelas V SD Gugus VIII Kecamatan Buleleng Kabupaten Buleleng Tahun Ajaran 2019/2020. Menurut Sugiyono (2017: 80), "populasi adalah wilayah generelasisasi yang teridiri atas sebuah objek atau subjek yang memiliki kualitas atau karakteristik tertentu yang didtetapkan oleh peneliti untuk dipelajari dan kemudian ditarik kesimpulannya". Kelas yang dijadikan populasi dalam penelitian akan diuji kesetaraan terlebih dahulu kemudian dilakukan teknik pengundian. Untuk mengukur kesetaraan dari populasi menggunakan uji analisis varians satu jalur (Anava-A), dengan kriteria pengujian yaitu apabila $\mathrm{f}_{\text {hitung }}$ lebih kecil dari $\mathrm{f}_{\text {tabel }}$ berdasarkan taraf signifikansi $5 \%$ maka populasi dinyatakan setara. Teknik pemilihan sampel yang digunakan untuk memilih kelas eksperimen dan kelas kontrol adalah dengan menggunakan teknik simple random sampling. Lima kelas yang masuk dalam populasi akan dirandom untuk menentukan kelas yang akan dijadikan kelas kontrol dan eksperimen. Didapatkan kelas V SDN 2 Paket Agung yang berjumlah 40 siswa sebagai kelompok eksperimen dan kelas V SDN 1 Paket Agung 
yang berjumlah 41 siswa sebagai kelas kontrol yang tidak diberikan perlakuan model pembelajaran Problem Based Learning berbantuan media audio visual.

Metode tes yang digunakan untuk mengukur pemahaman konsep IPA siswa adalah tes pilihan ganda sebanyak 30 butir. Tes pemahaman konsep yang digunakan adalah berpedoman pada dimensi pemahaman konsep. Menurut Aderson \& Krathwohl (2010) pemahaman konsep merupakan suatu pemahaman dasar yang dapat dikategorikan kedalam tujuh dimensi proses kognitif yaitu, menginterprestasi, mencontohkan, mengkategorikan, meringkas, memperkirakan, memadukan, dan menerangkan. Data yang diperoleh dalam penelitian ini akan dianalisis dengan metode analisis deskriptif berupa mean, median, modus dan standar deviasi. Dilanjutkan dengan analisis inferensial berupa uji normalitas, uji homogenitas, dan uji hipotesis. Adapun uji prasyarat analisis yang digunakan yaitu uji normalitas sebaran data menggunakan analisis Kolmogorov-Smirnov dan Shapiro-Wilk dengan kriteria pengujan jika signifikansi Kolmogorov-Smirnov $\geq 0,05$ maka kedua sampel berdistribusi normal, sebaliknya jika signifikansi Kolmogorov-Smirnov< 0,05 maka kedua sampel tidak normal. Sedangkan dasar pengambilan keputusan untuk teknik analisis Shapiro-Wilk yaitu sebagai berikut, jika nilai Sig. > 0,05, maka data berdistribusi normal, dan jika nilai Sig. < 0,05, maka data tidak berdistribusi normal. . Uji prasyarat analisis yaitu uji homogenitas dengan analisisTest of Homogeneity of Variancedengan kriteria pengujian jika signifikansi pada kolom sig $\geq 0,05$ maka kedua kelompok bersifat homogen, dan jika signifikansi $<0,05$ maka kedua kelompok tidak homogen. Setelah uji prasyarat dilakukan pengujian hipotesis menggunakan uji independen sample t-test (uji-t). Teknik analisis data pada penelitian ini dihitung dengan bantuan SPSS 20.00 for windows.

\section{HASIL DAN PEMBAHASAN}

\section{HASIL}

Berdasarkan analisis deskritif pada skor posttest diperoleh hasil rata-rata (mean) skor pemahaman konsep IPA siswa kelompok eksperimen 23,05, sedangkan kelompok control 21,31. Median pemahaman konsep IPA kelompok eksperimen sebesar 23,00, sedangkan kelompok kontrol 21,00. Modus pemahaman konsep IPA kelompok eksperimen sebesar 25,5 sedangkan kelompok kontrol 22,1. Standar deviasi pemahaman konsep IPA kelompok eksperimen sebesar 3,85 sedangkan kelompok kontrol 3,61.. Adapun tabel yang menunjukkan deskripsi data dapat dilihat pada tabel 2 .

Tabel 2. Deskripsi Data Kelompok Eksperimen dan Kelompok Kontrol

\begin{tabular}{ccc}
\hline Sumber Variansi & Eksperimen & Kontrol \\
\hline Skor Maksimal & 30 & 29 \\
Skor Minimal & 13 & 13 \\
Mean & 23.05 & 21,31 \\
Median & 23 & 21 \\
Modus & 25 & 22,1 \\
Standar Deviasi & 3,86 & 3,61 \\
Varians & 14,87 & 13,07 \\
\hline
\end{tabular}

Berdasarkan data tersebut, skor rata-rata pemahaman konsep IPA pada kelompok eksperimen melalui model Problem Based Learningberbantuan media audio visual lebih tinggi dari kelompok kontrol dengan dibelajarkan dengan tidak menggunakan model Problem Based Learningberbantuan media audio visual.

Adapun rata-rata ideal $\left(\mathrm{M}_{\mathrm{i}}\right)=15$ dan standar deviasi ideal $\left(\mathrm{SD}_{\mathrm{i}}\right)=5$. Jika dimasukkan ke dalam konversi hasil post test diperoleh skor pemahaman konsep IPA kelompok eksperimen sebesar 23,05 tergolong sangat tinggi. Sedangkan skor pemahaman konsep IPA 
kelompok kontrol jika dimasukkan ke dalam konversi hasil post test diperoleh skor pemahaman konsep IPA sebesar 21,31 tergolong tinggi.

Sebelum melakukan pengujian hipotesis data yang diperoleh, terlebih dahulu dilakukan uji normalitas sebaran data. Hasil pengujian normalitas data pemahaman konsep IPA kelas eksperimen dan kontrol dapat dilihat pada tabel 3 berikut.

Tabel 3. Hasil Pengujian Normalitas Sebaran Data Hasil Belajar IPA

\begin{tabular}{lcccccc}
\hline & \multicolumn{3}{c}{ Kolmogorof-Smirnov $^{\text {a }}$} & \multicolumn{3}{c}{ Shapiro-Wilk } \\
\hline & Statistic & Df & Sig. & Statistic & Df & Sig. \\
\hline Kelas Eksperimen & .118 & 40 & .165 & .969 & 40 & .334 \\
Kelas Kontrol & .130 & 41 & .079 & .971 & 41 & .383 \\
\hline
\end{tabular}

Berdasarkan Tabel 3 untuk analisis menggunakan Kolmogorov-Smirnov, diperoleh nilai sig untuk kelas eksperimen dan kelas kontrol masing-masing sebesar 0,165 dan 0,079. Nilai sig ini lebih besar daripada 0,05 , sehingga skor post-test kedua kelas berdistribusi normal. Dari hasil analisis menggunakan Shapiro-Wilk juga diperoleh nilai sig untuk kelas eksperimen dan kelas kontrol masing-masing sebesar 0,334 dan 0,383. Nilai sig ini lebih besar daripada 0,05 , sehingga memberikan simpulan sama yaitu skor posttest kedua kelas berdistribusi normal.

Tabel 4 . Hasil Pengujian Homogenitas Post-test Kelompok Eksperimen dan Kontrol

\begin{tabular}{cccc}
\hline Levene Statistic & df1 & df2 & Sig. \\
\hline .177 & 1 & 79 & 0.675 \\
\hline
\end{tabular}

Berdasarkan data pada tabel 4 di atas, diperoleh $\mathrm{F}$ (levene statistic) $=0,177, \mathrm{df} 1=1$, df2 $=79$, dan sig. $=0,65>0,05$. Sehingga dapat dilihat nilai signifikan pada kolom signifikan Test of Homogeneity of Variancce adalah 0,675. Hasil ini menunjukkan harga signifikan tersebut lebih besar dari 0,05. Sehingga data hasil penelitian post-test pada kelompok eksperimen dan kontrol dinyatakan homogen.Dari hasil uji prasyarat yaitu uji normalitas dan homogenitas, diperoleh bahwa data pemahaman konsep IPA dari kelompok eksperimen dan kelompok kontrol berdistribusi normal dan homogen.

Tabel 5. Uji Hipotesis

\begin{tabular}{|c|c|c|c|c|c|c|c|c|c|c|}
\hline & & \multirow[t]{2}{*}{$\mathrm{T}$} & \multirow[t]{2}{*}{ Sig } & \multirow[t]{2}{*}{$\mathrm{T}$} & \multirow[t]{2}{*}{ df } & \multirow{2}{*}{$\begin{array}{c}\text { Sig. } \\
(2- \\
\text { tailed })\end{array}$} & \multirow[t]{2}{*}{$\begin{array}{c}\text { Mean } \\
\text { Differen } \\
\text { ce }\end{array}$} & \multirow{2}{*}{$\begin{array}{c}\text { Std. } \\
\text { Error } \\
\text { Differen } \\
\text { ce }\end{array}$} & \multicolumn{2}{|c|}{$\begin{array}{c}95 \% \text { Confidence } \\
\text { Interval of the } \\
\text { Difference }\end{array}$} \\
\hline & & & & & & & & & Lower & Upper \\
\hline \multirow[t]{2}{*}{$\begin{array}{l}\text { Pemahaman } \\
\text { Konsep }\end{array}$} & $\begin{array}{l}\text { Equal } \\
\text { varian } \\
\text { ces } \\
\text { assum } \\
\text { ed } \\
\end{array}$ & $\begin{array}{l}.1 \\
77\end{array}$ & .675 & $\begin{array}{l}2 . \\
08 \\
7\end{array}$ & 79 & .040 & 1.73293 & .83033 & .08019 & 3.385 \\
\hline & $\begin{array}{l}\text { Equal } \\
\text { varian } \\
\text { ces not } \\
\text { assum } \\
\text { ed }\end{array}$ & & & $\begin{array}{l}2 . \\
08 \\
5\end{array}$ & $\begin{array}{l}78.37 \\
5\end{array}$ & .040 & 1.73293 & .83100 & .07866 & $\begin{array}{l}3.3871 \\
9\end{array}$ \\
\hline
\end{tabular}

Dari hasil analisis diperoleh diperoleh $\mathrm{t}$ hitung adalah 2,087 dan $\mathrm{t}^{\text {tabel }}$ pada taraf signifikansi 5\% dan $\mathrm{db}(40+41-2)=79$ adalah 2,00 . Hal ini berarti, $\mathrm{t}^{\text {hitung }}$ lebih besar dari $\mathrm{t}^{\text {tabel }}\left(\mathrm{t}^{\text {hitung }}>\mathrm{t}^{\text {tabel}}\right)$ 2,087 $>2,00$. Sehingga $\mathrm{H0}$ ditolak dan H1 diterima. Selain itu nilai sig pada kolom sig (2-tailed) dan baris equal variances assumed sebesar 0,040. nilai sig ini lebih kecil dari pada 0,05 Berdasarkan analisis tersebut, dapat diintrepretasikan bahwa 
terdapat perbedaan yang signifikan pemahaman konsep IPA pada mata pelajaran IPA antara kelompok siswa yang belajar dengan model pembelajaran Problem Based Learningberbantuan media audio visualdengan siswa yang dibelajarkan dengan tidak menggunakan model pembelajaran Problem Based Learningberbantuan media audio visualpada siswa kelas V Sekolah Dasar di Gugus VIII Kecamatan Buleleng tahun Pelajaran 2019/2020.

\section{PEMBAHASAN}

Berdasarkan penelitian yang telah dilakukan pada kelompok eksperimen dan kelompok kontrol terdapat beberapa hal yang ditemukan diantaranya sebagai berikut.

Hipotesis dalam penelitian ini telah berhasil menolak $\mathrm{H} 0$ dan menerima $\mathrm{H} 1$. Hal ini dibuktikan dari hasil uji-t, yang menyatakan t hitung adalah 2,087 dan ttabel pada taraf signifikansi $5 \%$ dan db $(40+41-2)=79$ adalah 2,00. Hal ini berarti, thitung lebih besar dari $t_{\text {tabel }}\left(t_{\text {hitung }}>t_{\text {tabel }}\right) 2,087>2,00$. Sehingga H0 ditolak dan H1 diterima. Jadi dapat dikatakan bahwa pembelajaran yang menggunakan model pembelajaran Problem Based Learning berbantuan media Auido Visual yang diterapkan pada mata pelajaran IPA lebih baik dalam meningkatkan pemahaman konsep IPA dari pada tidak menggunakan model pembelajaran Problem Based Learningberbantuan media Auido Visual.

Penelitian ini dibuktikan juga melalui skor rata-rata pemahaman konsep IPA siswa tergolong tinggi pada kelompok yang dibelajarkan dengan model pembelajaran Problem Based Learningberbantuan media Auido Visual (kelas eksperimen) yaitu 23,03 yang lebih besar dari pada skor rata-rata siswa yang tidak dibelajarkan dengan menggunakan model pembelajaran Problem Based Learnin gberbantuan media Auido Visual yaitu 21,31. Secara deskriptif, pemahaman konsep IPA siswa pada kelompok eksperimen lebih tinggi dibandingkan dengan pemahaman konsep IPA pada kelompok kontrol. Hal ini disebabkan dalam kegiatan pembelajaran pada model Problem Based Learning berbantuan media auido visual memungkinkan siswa memperoleh pengetahuan dengan melakukan penemuannya sendiri dalam melakukan sebuah percobaan dan bukan hasil mengingatngingat, serta guru lebih mengutamakan proses dan keterampilan dalam berfikir mulai dari menganalisis masalah sampai mengkomunikasikannya yang membuat siswa aktif hal ini sejalan dengan pendapat Irwandi dan Swarabama (dalam Noviar \& Hastuti (2015). Sedangkan pada kelompok kontrol yang tidak menggunakan model pembelajaran Problem Based Learningberbantuan media Auido Visual aktivitas siswa relatif rendah karena dalam proses pembelajaran hanya berfokus pada guru sehingga siswa kurang aktif dalam proses pembelajaran.

Model pembelajaran Problem Based Learning berbantuan media audio visual membuat siswa mampu mengembangkan pikiran dan aktif dalam mengikuti pembelajaran, karena pembelajaran yang dilaksanakan lebih banyak melakukan pemecahan masalah melalui percobaan sehingga menyenangkan bagi siswa. Hal ini sejalan dengan kelebihan dari model Problem Based Leraning, yaitu menurut Anwar (2017) diantaranya: (a) Model pemecahan masalah dapat merangsang munculnya kemampuan dan memberikan kepuasan untuk menentukan pengetahuan baru bagi peseta didik, (b) Pemecahan masalah dapat meningkatkan aktivitas pembelajaran peseta didik dalam proses belajar dikelas, (c) Model pemecahan masalah dapat membantu peserta didik menghubungkan pengetahuan dan pengalamannya dalam memahami masalah dalam kehidupan nyata, (d) Model pembelajaran pemecahan masalah dianggap lebih menyenangkan dan disuaki oleh peserta 
didik, dan (e) Model pemecahan masalah dapat memberikan kesempatan pada peserta didik untuk mengaplikasikan pengetahuannya dalam dunia nyata

Temuan penelitian ini menunjukkan bahwa model pembelajaran Problem Based Learning berbantuan media audio visual berbengaruh positif dalam pemahaman konsep IPA dengan kecenderungan sebagian besar skor siswa tinggi disebabkan oleh beberapa faktor. Guru dalam pembelajaran menggunakan lima fase dalam pemebelajaran, diantaranya pada fase 1 Guru mengorientasikan siswa terhadap masalah dimana siswa akan diberikan stimulus untuk mengembangkan atau menggali pengetahuan sehingga siswa siap untuk dibelajar, selain itu pada tahap ini siswa diberikan sebuah permasalahan melalui audio visual sehingga dapat menumbuhkan perhatian siswa terhadap pembelajaran. Fase 2 Mengorientasikan siswa untuk belajar, pada tahap ini guru memberikan motivasi dan tujuan pemebelajaran yang akan dilaksanakan. Siswa membuat hipotesis terkait permasalahan yang diberikan dan guru memberikan alat untuk siswa melakukan percobaan. Fase 3 Membimbing penyelidikan individu atau kelompok, pada fase siswa melakukan percobaan dan guru adalah sebagai fasilitator membantu siswa yang mengalami kesulitan, jika seluruh kelompok pada kelas kesulita guru menjelaskan kembali. Fase 4 Mengembangkan dan menyajikan hasil karya, pada fase ini siswa menyampaikan hasil yang didapat kepada teman-temannya. Fase 5 Menganalisis dan mengevaluasi proses pemecahan masalah, guru bersama siswa melakukan evaluasi apa yang belum dipahami dan menyimpulkan apa yang telah didapatkan.

Tampak dari proses pembelajaran Problem Based Learning ini diawali dengan menggali pengetahuan awal atau apresepsi siswa terkait materi yang akan dikaji. Ini bertujuan agar siswa memiliki gambaran awal mengenai materi. Guru akan lebih mudah memberikan sebuah gambaran awal permasalahan melalui media audio visual. Karena media audio visual dapat menarik perhatian dan fokus siswa terhadap materi sehingga siswa dapat memahami betul materi permasalahan yang dikaji. Dalam memecahkan masalah terkait materi yang dikaji, siswa melakukan diskusi baik dalam mencari sumber, mengerjakan LKPD maupun melakukan percobaan untuk melatih kemampuan berfikir, menganalisa, menyimpulkan dan menemukan konsep akan dapat mengkontruksi pikirannya sendiri. Siswa juga dituntut mampu menyampaikan hasil yang didapat dihadapan teman-temannya, walaupun hasil yang didapat kurang tepat. Guru memberikan kesempatan terhadap siswa yang memiliki pendapat yang berbeda. Perbedaan pendapat antara siswa akan memacu terjadinya interaksi multiarah yaitu dari siswa ke siswa, dari siswa ke guru begitupun sebaliknya guru ke siswa yang akan menimbulkan pertukaran informasi yang lebih mendalam dan menarik sehingga menimbulkan rasa percaya diri siswa dalam menyampaikan suatu pendapat. Dalam hal ini guru hanya sebagai fasilitator dan mediator utuk menciptakan kondisi belajar yang efektif dan efisien dalam proses pembelajaran dimana guru menjadi penengah dan mengarahkan siswa supaya tidak terjadi miss konsepsi antar siswa, dengan menjelaskan kembali materi agar materi yang belum dimengerti dapat dimengerti siswa.

Berbeda halnya dalam proses pembelajaran dengan tidak menggunakan model pembelajaran Problem Based Learning berbantuan media audio visualyang membuat siswa lebih banyak belajar IPA secara prosedural. Dalam penelitian ini, guru lebih mendominasi kegiatan dalam proses pembelajaran. Sehingga siswa kurang aktif, karena siswa hanya berperan sebagai pendengar yang pasif serta siswa hanya mengerjakan apa yang disuruh dan melakukan apa yang hanya di contohkan guru. Dalam pembelajaran tanpa 
menggunakan model Problem Based Learning berbantuan media audio visualsiswa jarang diberikan kesempatan melakukan eksplorasi terhadap suatu masalah dengan cara pikiran sendiri. Pembelajaran seperti ini akan mengakibatkan siswa tidak terlatih untuk berinvestigasi dan hanya akan menunggu perintah dari guru. Selain itu masalah - masalah IPA yang bersifat kontekstual biasanya digunakan untuk menguji pemahaman siswa pada konsep yang telah dipelajari dan biasanya diberikan pada akhir pembahasan materi. Pemahaman yang diperoleh tentunya bersifat temporer karena pengetahuan yang diperoleh siswa hanya berdasarkan informasi dari guru. Sehingga akhibatnya akan mempengaruhi keingintahuan siswa dan keterkaitan terhadap dunia sekitar dengan mengobservasi maupun mengeksplorasi. Siswa akan memandang bahwa pelajaran IPA itu jauh dari dunianya.

Perbedaan cara pembelajaran antara pembelajaran dengan model pembelajaran Probelem Based Learning dan pembelajaran yang tidak menggunakan model pembelajaran Problem Based Learning, tentunya akan memberikan dampak yang berbeda pada tingkat pemahaman konsep siswa. Pembelajaran menggunakan model pembelajaran Problem Based Learning dalam proses pembelajaran memungkinkan siswa untuk mengetahui manfaat materi yan akan dipelajari bagi kehidupannya, menemukan sendiri konsep-konsep yang dipelajari tanpa harus tergantung pada guru, membuat siswa aktif dalam proses pembelajaran, mampu memecahkan masalah-masalah berkaitan dengan konsep yang dipelajari, berkerja sama dengan siswa lain, dan berani mengungkapkan atau mengemukakan pendapat. Dengan demikian pemahaman konsep IPA siswa yang diajar dengan model pembelajaran Problem Based Learning akan lebih baik dibandingkan dengan siswa yang tidak dibelajarkan dengan model pembelajaran Problem Based Learning.

\section{SIMPULAN}

Berdasarkan hasil pengujian hipotesis dan pembahasan dapat disimpulkan bahwa terdapat perbedaan yang signifikan pemahaman konsep siswa pada mata pelajaran IPA antara kelompok siswa yang dibelajarkan dengan model pembelajaran Problem Based Learning berbantuan media audio visual dengan siswa yang dibelajarkan dengan tidak menggunakan model pembelajaran Problem Based Learning berbantuan media audio visual pada siswa kelas V Sekolah Dasar di Gugus VIII Kecamatan Buleleng tahun Pelajaran 2019/2020. Model Problem Based Learning Berbantuan Media Audio Visual dapat meningkatkan Pemahaman Konsep pada Pembelajaran IPA

\section{DAFTAR PUSTAKA}

Aderson, L. W., \& Krathwohl, D. (2010). Kerangka landasan untuk pembelajaran, pengajaran, dan asesmen. Addison Wesley Longman, Inc.

Anwar, C. (2017). Teori-teori Pendidikan Klasik Hingga Kontenporer. IRCiSod.

Fahturohman, P., \& Sutikno, S. (2011). Strategi Belajar Mengajar: Strategi Mewujudkan Pembelajaran Bermakna Melalui Penanaman Konsep Umum \& Konsep Islami. PT Refika Aditama.

Gading, I. K., Suja, W., Sudarma, I. K., Divayana, D. G. H., \& Widiana, I. W. (2018). Belajar dan Pembelajaran. Undiksha Press.

Hadi, S., \& Novaliyosi, N. (2019). Timss Indonesia (Trends in International 
Mathematics and Science Study). In Prosiding Seminar Nasional \& Call For Papers.

Hakim, M. A. A., Sunarto, \& Totalia, S. A. (2016). Penerapan Model Pembelajaran Problem Based Learning (PBL) untuk Meningkatkan Hasil Belajar Peserta Didik Kelas XI IIS dalam Mata Pelajaran Ekonomi Di SMAN 5 Surakarta Tahun Ajaran 2015/2016. Pendidikan Ekonomi, FKIP Universitas Sebelas Maret, 2(2), 1-13.

Hastuti, A., \& Budianti, Y. (2014). Pengaruh Penggunaan Media Audio Visual Terhadap Hasil Belajar Siswa Pada Mata Pelajaran IPA Kelas II SDN Bantargebang II Kota Bekasi. Pedagogik (Jurnal Pendidikan Sekolah Dasar), 2(2), 33-38.

Kadir, A. (2015). Perbandingan Pengetahuan Lingkungandan Sikap Peserta Didik Dalam Peneerapan Model Pembelajaran SETS dan Konvensional. Al-Izzah, 11(2), 1-18.

Kono, R. (2016). Pengaruh Model Problem Based Learning (PBL) Terhadap Pemahaman Konsep Biologi Dan Keterampilan Berpikir Kritis Siswa Tentang Ekosistem Dan Lingkungan Di Kelas X SMA Negeri. JSTT, 5(1).

Lumentut, C. P., Ali, M. T. M., \& Hasbi, M. (2015). Peningkatan Hasil Belajar Siswa Kelas VIII SMPN 14 Palu dengan Model Pembelajaran Kooperatif Tipe NHT berbantuan Blok Aljabar pada Materi Perkalian Faktor Bentuk Aljabar. Jurnal Elektronik Pendidikan Matematika Tadulako, 2(3).

Nafiah, Y. N., \& Suyanto, W. (2014). Penerapan model problem-based learning untuk meningkatkan keterampilan berpikir kritis dan hasil belajar siswa. Jurnal Pendidikan Vokasi, 4(1), 125-143.

Nasional, D. pendidikan. (2003). Undang-undang Nomor 20 Tahun 2003 Tentang Sistem Pendidikan Nasional. Depdiknas.

Noviar, D., \& Hastuti, D. R. (2015). Pengaruh model problem based learning (PBL) berbasis scientific approach terhadap hasil Belajar Biologi Siswa Kelas X di SMA N 2 Banguntapan Tahun Ajaran 2014/2015. Bioedukasi: Jurnal Pendidikan Biologi, 8(2), 42-47.

Permana, Rakhmad, \& Hidayatulloh. (2019). Survei Kualitas Pendidikan PISA 2018: RI Sepuluh Besar dari Bawah. DetikNews (Online).

Pramita, A., \& Agustini. (2016). Pengembangan Media Permainan Ular Tangga Pada Materi Senyawa Hidrokarbon Kelas XI SMA Untuk Meningkatkan Pemahaman Konsep Siswa. Unesa Journal of Chemical Education, 5(2), 336344.

Purnamawati, A. K., Suardika, R. W., \& Manuaba, I. s. (2014). Pengaruh Model Pembelajaran Kontekstual Berbasis Lingkungan Terhadap Hasil Belajar IPA Siswa Kelas V SD Di Gugus I Gusti Ngurah Rai. MIMBAR PGSD Undiksha, 2(1).

Riananda, L., \& Nurdyansyah. (2017). Developing ICT-Based Learning Model to Improve Learning Outcomes IPA of SD Fish Market in Sidoarjo. Proceedings of International Research Clinic \& Scientific Publications of Educational 
Technology, 929-940.

Sadiqin, I. K., Santoso, U. T., \& Sholahuddin, A. (2017). Pemahaman Konsep IPA Siswa SMP Melalui Pembelajaran Problem Solving Pada Topik Perubahan Benda-benda Di Sekitar Kita. Jurnal Inovasi Pendidikan IPA, 3(1), 52-62. https://doi.org/10.21831/jipi.v3i1.12554

Saleh, M. (2013). Strategi Pembelajaran Fiqh dengan Problem-Based Learning. JURNAL ILMIAH DIDAKTIKA, 14(1).

Samatowa, U. (2010). Pembelajaran IPA di Sekolah Dasar. PT Indeks.

Santosa, D. S. S. (2018). Manfaat Pembelajaran Kooperatif Team Games Tournament (TGT) dalam Pembelajaran. Ecodunamika, 1(3).

Saputro, C. B. (2017). Meningkatkan Hasil Belajar Sifat-sifat Cahaya Dengan Metode Inquiri Pada Kelas V SD Negeri Sumoga We 04. Jurnal Mitra Pendidikan, 1(9), 925-937.

Setyawati, N. W. I., Candiasa, I. M., Kom, M. I., \& Yudana, I. M. (2014). Pengaruh Model Pembelajaran Inkuiri Terbimbing terhadap Pemahaman Konsep dan Keterampilan Proses Sains Siswa Kelas XI IPA SMA Negeri 2 Kuta Kabupaten Badung. Jurnal Administrasi Pendidikan Indonesia, 5(1).

Simbolon, M. (2017). Penerapan Model Kooperatif dalam Meningkatkan Motivasi serta Kreativitas dan Hasil Belajar Siswa di SMP Negeri 5 Tebing Tinggi. School Educational Journal PGSD FIP Unimed, 7(3), 353-362.

Sinabariba, R. B. (2017). Peranan Guru Memilih Model-Model Pembelajaran Untuk Meningkatkan Kemampuan Menulis Puisi. Seminar Nasional Pendidikan Dasar Universitas Negeri Medan. https://osf.io/preprints/inarxiv/c672m/

Sugiyono. (2017). Metode Penelitian Pendidikan (Pendekatan Kuantitatif, Kualitatif, dan $R \& D)$. Alfabeta.

Sukiman. (2012). Pengembangan Media Pembelajaran. PT. Pustaka Insan Persada.

Susanto, A. (2013). Teori Belajar dan Pembelajaran di Sekolah Dasar. Kencana.

Trianto. (2007). Model-model Pembelajaran Inovatif Berorientasi Konstruktivistik. Prestasi Pustaka.

Widyanto, P. (2016). Penerapan Metode Pembelajaran Group Investigation Berbantuan Media Flanelgraf Untuk Meningkatkan Minat Dan Hasil Belajar Siswa Pada Mata Pelajaran IPA (Studi Kelas IV SDN Jetak 01, Kecamatan Getasan, Kabupaten Semarang). Jurnal Pendidikan Dasar Nusantara, 3(1), $118-129$.

Wisudawathi Widi Asih, \& Sulistyowati, E. (2014). Metodelogi Pembelajaran IPA. Bumi Aksara. 